\title{
The crystal structure of uytenbogaardtite, $\mathrm{Ag}_{3} \mathrm{AuS}_{2}$, and its relationships with gold and silver sulfides-selenides
}

\author{
LUCA Bindi ${ }^{1}{ }^{*}$, CHRISTOPHER J. STANLEY $^{2}$, YURII V. SERYOTKIN ${ }^{3,4}$, VLADIMIR V. BAKAKIN $^{5}$, \\ GALINA A. PAL'YANOVA ${ }^{3,4}$, KONSTANTIN A. KOKH ${ }^{3,4}$ \\ ${ }^{1}$ Dipartimento di Scienze della Terra, Università di Firenze, Via G. La Pira 4, I-50121Firenze, Italy \\ ${ }^{2}$ Natural History Museum, Cromwell Road, London SW7 5BD, United Kingdom \\ ${ }^{3}$ Sobolev Institute of Geology and Mineralogy of the Siberian Branch of the Russian Academy of Sciences, pr. \\ Akademika Koptyuga, 3, Novosibirsk 630090, Russia \\ ${ }^{4}$ Novosibirsk State University, Pirogova str., 2, Novosibirsk 630090, Russia \\ ${ }^{5}$ Institute of Inorganic Chemistry, Siberian Branch of the RAS, prosp. Lavrentieva 3, 630090 Novosibirsk, Russia \\ *e-mail address: luca.bindi@unifi.it
}

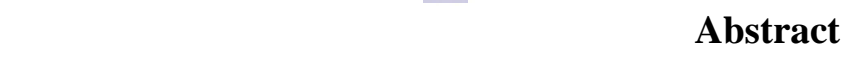

The crystal structure of the mineral uytenbogaardtite, a rare silver-gold sulfide, was solved using intensity data collected on a crystal from the type locality, the Comstock lode, Storey County, Nevada (U.S.A.). The study revealed that the structure is trigonal, space group $R \overline{3} c$, with cell parameters: $a=13.6952(5), c=17.0912(8) \AA$, and $V=2776.1(2) \AA^{3}$. The refinement of an anisotropic model led to an $R$ index of 0.0140 for 1099 independent reflections. The structure consists of a sublattice of sulfur atoms forming a distorted body-centered cubic arrangement. The structure contains distinct tri-atomic linear groups $(\mathrm{S}-\mathrm{Au}-\mathrm{S})$ and $\mathrm{Ag}$ atoms bonded to four $\mathrm{S}$ atoms (from four different linear groups) in a distorted tetrahedral arrangement. On the basis of information gained from this characterization, uytenbogaardtite is here definitively proved to be structurally different from petzite, $\mathrm{Ag}_{3} \mathrm{AuTe}_{2}$, and fischesserite, $\mathrm{Ag}_{3} \mathrm{AuSe}_{2}$. By means of high-quality single-crystal diffraction data, the 
symmetry of the mineral was found to be trigonal, and not tetragonal as erroneously supposed. A revaluation of the powder diffraction data listed in the scientific literature for uytenbogaardtite according to the structural results obtained here leads to an excellent agreement. Crystal-chemical features of uytenbogaardtite, $\mathrm{Au}_{2} \mathrm{~S}$, petrovskaite $\mathrm{AgAuS}$, uytenbogaardtite-fischesserite series $\mathrm{Ag}_{3} \mathrm{Au}\left(\mathrm{S}_{2-\mathrm{x}} \mathrm{Se}_{\mathrm{x}}\right)$ and acanthite-naummanite series $\mathrm{Ag}_{2}\left(\mathrm{~S}_{1-\mathrm{x}} \mathrm{Se}_{\mathrm{x}}\right)$ are compared.

Keywords: Crystal structure and symmetry; silver sulfides; gold sulfides; minerals; uytenbogaardtite.

\section{Introduction}

Uytenbogaardtite was defined as a new mineral species by Barton et al. (1978) during a study of the ores coming from three different regions: the Tambang Sawah, Benkoelen district, Sumatra (Indonesia), the Comstock lode, Storey County, Nevada (U.S.A.), and Zmeinigorsk, Altai, Russia. The mineral was found to form fine intergrowths with acanthite and electrum. An X-ray single-crystal study was not attempted by Barton et al. (1978) owing to the paucity of the mineral, and their structural study was limited to a low-quality X-ray powder investigation made difficult by the several coexisting phases in the selected material for the experiment. Barton et al. (1978) assigned a tetragonal cell of $a=9.76, c=9.78 \AA$ (Comstock lode), and $a=9.68, c=9.81 \AA$ (Tambang Sawah) to uytenbogaardtite, in relation with the studies done previously by Graf (1968) on the synthetic analogue.

Messien et al. (1966) reported the low-temperature $\mathrm{Ag}_{3} \mathrm{AuS}_{2}$ to be cubic, $a=9.72 \AA$, but Graf (1968) later argued that the symmetry is actually tetragonal. Observed reflections suggested a primitive space group with the only possible non-unit translational symmetry elements being $4_{1}$ - or a $4_{3}$-axis (Graf, 1968). This author also pointed out that given the fact 
that not many $00 \mathrm{l}$ reflections were observed it is not possible to ascertain with confidence if a four-fold screw axis is present with the probable space group being either $P 4_{1} 22$ or $P 4_{1}$.

Recently, Seryotkin et al. (2011) solved the crystal structure of synthetic $\mathrm{Ag}_{3} \mathrm{AuS}_{2}$ and found that the compound is actually trigonal, space group $R \overline{3} c$. These authors compared the trigonal structure of $\mathrm{Ag}_{3} \mathrm{AuS}_{2}$ with that of cubic petzite $\left(\mathrm{Ag}_{3} \mathrm{AuTe}_{2}\right)$ and fischesserite $\left(\mathrm{Ag}_{3} \mathrm{AuSe}_{2}\right)$ and found that it cannot be attributed to the petzite group, because it exhibits a new structure type. By means of the synthesis and structural characterization of gold-silver sulfoselenides belonging to the $\mathrm{Ag}_{3} \mathrm{Au}(\mathrm{Se}, \mathrm{S})_{2}$ series (i.e., $\mathrm{Ag}_{3} \mathrm{AuSe}_{1.5} \mathrm{~S}_{0.5}, \mathrm{Ag}_{3} \mathrm{AuSeS}$, and $\mathrm{Ag}_{3} \mathrm{AuSe}_{0.5} \mathrm{~S}_{1.5}$ ), Seryotkin et al. (2013a and references therein) proved the existence of two solid-solution series: petzite-type cubic $\mathrm{Ag}_{3} \mathrm{AuSe}_{2}-\mathrm{Ag}_{3} \mathrm{AuSeS}$ (space group $\mathrm{I4}_{1} 32$ ) and trigonal $\mathrm{Ag}_{3} \mathrm{AuSe}_{0.5} \mathrm{~S}_{1.5}-\mathrm{Ag}_{3} \mathrm{AuS}_{2}$ (space group $R \overline{3} c$ ). Both crystal structures differ in the distribution of $\mathrm{Ag}^{+} / \mathrm{Au}^{+}$cations in distorted body-centered cubic sublattices of $\mathrm{S} / \mathrm{Se}$ anions. The morphotropic transformation results from the shrinkage of anion packing accompanied by the shortening of $\mathrm{Ag}-\mathrm{Ag}$ distances with increase of $\mathrm{S}$ content.

In the course of a research project dealing with the description and structural characterization of natural silver and gold chalcogenides (Bindi 2008, 2009; Bindi and Cipriani, 2004a, 2004b; Bindi and Pingitore, 2013; Bindi et al., 2004, 2009, 2015), a fragment from the type locality (Comstock lode, Nevada) belonging to the mineralogical collections of the Natural History Museum of London (catalogue number E.1069, off BM 1983, 353) has been examined. Microscopic observations revealed that the sample consists of tiny uytenbogaardtite grains cut by veinlets of acanthite with gangue minerals of calcite and quartz.

To help resolve the concerns relating to the structure of uytenbogaardtite, new crystal structure data for the mineral from its type locality are presented here. We show that the 
structure of uytenbogaardtite mineral, earlier incorrectly interpreted as having a tetragonal cell, is identical to that of the synthetic trigonal $\mathrm{Ag}_{3} \mathrm{AuS}_{2}$ end-member.

\section{X-ray crystallography}

A small crystal fragment $(55 \times 61 \times 72 \mu \mathrm{m})$ was selected for the single-crystal X-ray diffraction study. The intensity data collection (see Table 1 for details) was carried out by means of an Oxford Diffraction Xcalibur 3 single-crystal diffractometer (X-ray radiation MoKa, $\lambda=0.71073 \AA$ ) fitted with a Sapphire 2 CCD detector. A total of 714 frames of data were collected at room temperature as 7 sets of omega runs with an exposure time of $80 \mathrm{~s}$ per frame and a frame width of $1.00^{\circ}$. This afforded an overall data collection of 47568 reflections (1099 unique). The refined unit-cell parameters are $a=13.6952(5), c=17.0912(8)$ $\AA$, and $V=2776.1(2) \AA^{3}$, which are in a very good agreement with those found by Seryotkin et al. (2011) $\left[a=13.7104(4) \AA, c=17.1170(6) \AA\right.$, and $\left.V=2786.5(2) \AA^{3}\right]$ for the synthetic $\mathrm{Ag}_{3} \mathrm{AuS}_{2}$

Data frames were processed using the CrysAlis software package (Oxford Diffraction, 2006) running on the Xcalibur 3 control PC. The program ABSPACK (Oxford Diffraction, 2006) was used for the absorption correction. The merging $R$ for the data set decreased from 0.114 before the absorption correction to 0.032 after this correction. The observed reflection conditions, together with the statistical tests on the distribution of $|E|$ values that strongly indicated the presence of an inversion centre $\left(\left|E^{2}-1\right|=0.957\right)$ and the indications from the previous structure solution by Seryotkin et al. (2011), pointed unequivocally to the choice of the space group $R \overline{3} c$. The structure solution was then initiated in this space group. The positions of the atoms were determined by means of direct methods (Sheldrick, 2008). The program SHELXL (Sheldrick, 2008) was used for the refinement of the structure. Neutral scattering curves for $\mathrm{Ag}, \mathrm{Au}$ and $\mathrm{S}$ were taken from the International Tables for X-ray 
Crystallography (Ibers and Hamilton, 1974). The occupancies of all sites were left free. They were found to be consistent with a full occupation by $\mathrm{Ag}$, $\mathrm{Au}$, and $\mathrm{S}$, respectively, and then fixed. At the last stage, with anisotropic atomic displacement parameters for all atoms and no constraints, the residual value settled at $R=0.0137$ for 907 observed reflections $\left[F_{\mathrm{o}}>4 \sigma\left(F_{\mathrm{o}}\right)\right.$ level] and 38 parameters and at $R=0.0140$ for all 1099 independent reflections. Inspection of the difference Fourier map revealed that maximum positive and negative peaks were 1.81 and $1.78 \mathrm{e}^{-} / \AA^{3}$, respectively. Experimental details and $R$ indices are given in Table 1 . Fractional atomic coordinates and anisotropic displacement parameters are reported in Table 2. Structure factors are deposited with the Principal Editor of Mineralogical Magazine at http://www.minersoc.org/pages/e journals/dep_mat.html. Bond distances are reported in Table 3.

\section{Optical properties}

Qualitative observations of uytenbogaardtite in plane polarized reflected light are broadly in agreement with those of Barton et al. (1978). Under low power microscopic examination there is only a subtle difference between different orientations of uytenbogaardtite and the associated acanthite, both appearing a slightly bluish-grey against the dark grey gangue minerals calcite and quartz in association with pyrite (Fig. 1). However, observations using higher magnification objectives show that uytenbogaardtite is distinctly pleochroic in shades of slightly pinkish grey to slightly higher reflecting greenish grey against cross-cutting veins of acanthite (Fig. 2a). Moreover, at such higher magnification the mineral is distinctly light sensitive. For this reason, fully quantitative reflectance measurements were not made as the length of time taken to make measurements exceeded the period of relative stability prior to reaction and spotting of the uytenbogaardtite surface became obvious. 
It was observed during the light sensitivity reaction that orientations closer to $R_{0}$ the basal section in uniaxial minerals, were more susceptible and hence more reactive presumably because electrons in the conduction band in this orientation are more easily excited by photons (Fig. 2b). In Figure 2 the slightly higher reflecting greenish grey orientation of uytenbogaardtite on the right of the image is close to $R_{0}$, while the slightly pinkish grey orientation is probably close to $R_{\mathrm{e}}$. Since $R_{\mathrm{o}}>R_{\mathrm{e}}$ the mineral is uniaxial negative. In partially crossed polars, anisotropic rotation tints determined on the latter (Fig. 3) are from a pale green to deep purple.

\section{Results and Discussion \\ Crystal structure of uytenbogaardtite}

In the crystal structure of uytenbogaardtite, the $\mathrm{Ag}$ atoms are located in two crystallographically non-equivalent general positions. The four S atoms around each silver atom form an irregular tetrahedron. The Au atoms occupy also two crystallographically nonequivalent positions. Each of them is coordinated by two $\mathrm{S}$ atoms at a distance of $2.33-2.37 \AA$ at an $\mathrm{S}-\mathrm{Au}-\mathrm{S}$ angle of $\approx 180^{\circ}$; in addition, each $\mathrm{Au}$ atom has six $\mathrm{Ag}$ atoms as its neighbors at a distance of $2.90-3.14 \AA$.

The structure may be described on the basis of infinite columns of edge-sharing $\left[\mathrm{AgS}_{4}\right]$ sphenoids additionally connected by $\left[\mathrm{AuS}_{2}\right]$ coordinations situated along threefold symmetry axes (Fig. 4). The crystal-chemical formula of uytenbogaardtite is ${ }^{[4]} \mathrm{Ag}_{12}$ $\left({ }^{[2]} \mathrm{Au}^{(7)} \mathrm{S}_{2}\right)\left({ }^{[2 \mathrm{n}]} \mathrm{Au}^{(7)} \mathrm{S}_{2}\right)_{3}$ where the coordination number of a cation is enclosed in square brackets and that of an anion in parentheses. The building unit of the column, $\mathrm{Ag}_{12} \mathrm{Au}_{4} \mathrm{~S}_{20}$, consists of four $\mathrm{S}-\mathrm{Au}-\mathrm{S}$ linear groups (one of them lies on the column axis) and $2 \times 6 \mathrm{Ag}$ tetrahedra (Fig. 4b). Multiplication of the building units by $c$ symmetry plane forms the columns of uytenbogaardtite. The building units are joined in columns via six $\mathrm{S}^{2-}$ anions. 
Columns mutually joined by shared edges of Ag-tetrahedra are multiplied by base translations of rhombohedral lattice.

There are two types of $\mathrm{S}-\mathrm{Au}-\mathrm{S}$ complexes: strictly linear located along the column axis and slightly bent (indicated as "2n" (Lima-de-Faria et al., 1990)) with the angle $\left(\mathrm{S}-{ }^{\left[{ }^{2 n}\right]} \mathrm{Au}-\mathrm{S}\right)$ of $179.35^{\circ}$. The complexes of the second type are located on the periphery of the columns.

The structure of the natural uytenbogaardtite is very similar to that of synthetic compound $\mathrm{Ag}_{2.94} \mathrm{Au}_{1.06} \mathrm{~S}_{2}$ (Seryotkin et al., 2011), excluding the low-occupied Au3 site lacking in the structure of the current mineral sample. This disagreement is explained by the presence of $\mathrm{AgAuS}$ (petrovskaite) inclusion in the synthetic sample. A minor portion of this compound could affect the crystal data due to a topotactic integrowth of the two structures with similar anion sublattices (Seryotkin et al., 2014).

\section{Comparison with the crystal structures of $\mathrm{Au}$ - and Ag-sulfoselenides}

Anion sublattice of many chalcogenides in this group is described according to the body-centered cubic packing (bcc) model. Such sublattice may be divided entirely into distorted tetrahedra or sphenoids (Bakakin, 2011; Seryotkin et al., 2011). A part of sphenoids are occupied by Ag atoms; Au atoms are situated at the edges of vacant sphenoids. Thus, the structural features of a given compound are defined by the occupation of sphenoids by cations and by steric parameters of anions which form the sublattice.

The compounds with common formulae $(\mathrm{Ag}, \mathrm{Au})_{2}(\mathrm{~S}, \mathrm{Se})$ are listed in Table 4 . In these structures the sublattice of $\mathrm{S}$ - and Se-atoms forms a distorted (excluding $\mathrm{Au}_{2} \mathrm{~S}$ ) body-centered cubic arrangement. It should be noticed that normalized volumes $V_{\mathrm{N}}$ (Bakakin and Seryotkin, 2009) are fairly close for the listed compounds $\left(19.3-21.1 \AA^{3}\right)$.

Worthy to note, the grade of distortion of anion sublattice does not relate directly to the symmetry of compound. The deviation from ideal bcc depends on deformation of its two- 
anionic subcell. Generally, the unit cell comprises several subcells, so the crystal symmetry depends on their combination. Coincidence of symmetries of anion sublattice and entire crystal structure was found only for $\mathrm{Au}_{2} \mathrm{~S}(Z=2$, Ishikawa et al., 1995) and argentite, high temperature phase of $\operatorname{Ag}_{2} \mathrm{~S}(Z=2$, Cava et al., 1980). In other related structures (Table 4) the unit cell comprises from 2 (acanthite, naumannite) to 24 (uytenbogaardtite) subcells in anion sublattice.

The compounds containing linear $\mathrm{X}^{-[2]} \mathrm{M}-\mathrm{X}$ groups in the structure have symmetry axis of third order. Silver chalcogenides without the linear groups are of lower symmetry. The meaningful example is cubic $\mathrm{Au}_{2} \mathrm{~S}$ which has only linear groups in the structure. $\mathrm{Au}^{+}$cations are located collinearly on body diagonals of anion bcc cells forming two interpenetrating three-dimensional networks with $\mathrm{S}^{2-}$ in tetrahedral coordination. The anion subsystem corresponds to ideal body-centered cubic packing.

Addition of cation with coordination number $>2$ to linearly coordinated $\mathrm{Au}^{+}$results in the change of bonding system in the chalcogenide structure. Depending on the ratio of cations with different coordination, the three dimensional network of linear groups transforms to another configuration or breaks into fragments (chains, rings, single linear groups). For instance, in orthorhombic NaAuS with bcc anion packing the $\mathrm{Na}^{+}$cations in tetrahedral coordination are joined in a framework, and the $\left({ }^{[2 n]} \mathrm{Au}-\mathrm{S}\right)^{\infty}$ chains coil in an unusual fashion so that they are interwoven to form layers reminiscent of "chicken-wire" (Axtell et al., 1998).

Three fourths of $\mathrm{Ag}^{+}$cations form a tetrahedral framework in rhombohedral petrovskaite AgAuS. The linear groups $\mathrm{S}-(\mathrm{Au}, \mathrm{Ag})-\mathrm{S}$ form four interpenetrating threedimensional networks (Seryotkin et al., 2014). The number of Au cations alone is not enough to form the networks, so a fourth part of $\mathrm{Ag}^{+}$gained linear coordination. The detailed crystalchemical formula of petrovskaite with cation ratio ${ }^{[2]} \mathrm{M}:{ }^{[4]} \mathrm{M}=5: 3$ may be written as ${ }^{[4]} \mathrm{Ag}_{6}$ ${ }^{[2]} \mathrm{Ag}^{[2]}\left(\mathrm{Ag}_{0.33} \mathrm{Au}_{0.67)}{ }^{[2 n]} \mathrm{Au}_{6}{ }^{(6)} \mathrm{S}_{6}{ }^{(4)} \mathrm{S}_{2}\right]$, or simplified ${ }^{[4]} \mathrm{Ag}_{3}\left[{ }^{[2]} \mathrm{Ag}^{[2]} \mathrm{Au}_{4}{ }^{(6)} \mathrm{S}_{3}{ }^{(4)} \mathrm{S}\right]$. The sublattice 
of sulfur anions has a strongly distorted bcc arrangement, caused by specific coordination of $\mathrm{S}^{2-}$. Three fourths of anions are one-side coordinated by two $\mathrm{Au}^{+}$and four $\mathrm{Ag}^{+}$. The remaining part has only four neighboring $\mathrm{Au}^{+}$forming a regular tetrahedron.

Uytenbogaardtite has a ratio ${ }^{[2]} \mathrm{M}:{ }^{[4]} \mathrm{M}=1: 3$ and its structure contains only isolated $\mathrm{S}_{-}$ $\mathrm{Au}-\mathrm{S}$ linear groups. In spite of the different coordination of cations, the deviation of anion sublattice from the bcc arrangement is quite small. All anions have similar coordination, which is likely to explain with the lower degree of distortion of anion sublattice compared to petrovskaite.

The structure of cubic fischesserite is composed of secondary building units of the same topology as in structure of uytenbogaardtite (Seryotkin et al., 2011). The difference is in the manner of multiplication of building units in columns. In the uytenbogaardtite case, multiplication is realized by means of reflection and a translation shift by the $c$ symmetry plane. In the fischesserite structure, they are multiplied by translation along the body diagonal without reflection. Both crystal structures differ in the distribution of $\mathrm{Ag}^{+} / \mathrm{Au}^{+}$cations. As a result, bcc sublattice of fischesserite is more distorted than that of uytenbogaardtite.

The structure of uytenbogaardtite tolerates the substitution of up to $40 \%$ of sulfur atoms by selenium. Two solid-solution $\mathrm{Ag}_{3} \mathrm{AuS}_{2}-\mathrm{Ag}_{3} \mathrm{AuSe}_{2}$ series exist: trigonal uytenbogaardtitelike $\mathrm{Ag}_{3} \mathrm{AuS}_{2}-\mathrm{Ag}_{3} \mathrm{AuSe}_{0.75} \mathrm{~S}_{1.25}$ and cubic fischesserite-like $\mathrm{Ag}_{3} \mathrm{AuSeS}-\mathrm{Ag}_{3} \mathrm{AuSe}_{2}$ (Seryotkin et al., 2013a,b). The morphotropic transformation between the two structure types results from the shrinkage of anion packing accompanied by the shortening of $\mathrm{Ag}-\mathrm{Ag}$ distances. It is generally assumed that the $\mathrm{Ag}-\mathrm{Ag}$ interactions help to stabilize the structures of $\mathrm{Ag}-$ chalcogenides (Makovicky, 2006). However, the stabilizing effect of such interaction is limited to a certain range of interatomic distances, and an excessive shortening may cause instability of the crystal structure. For instance the S-S distances in the pseudocubic arrangement in uytenbogaardtite vary in the range $3.81-4.74 \AA$ with a mean value of $4.22 \AA$, 
whereas the range observed in fischesserite is $3.43-5.20 \AA$, with a mean value of $4.33 \AA$. Since the $\mathrm{Ag}-\mathrm{Ag}$ distance is equal to $2.89 \AA$ in metal silver (Spreadborough and Christian, 1959), it can be assumed that the approach to this value is critical. Probably the same interaction causing destabilization of the fischesserite-like crystal structure causes the morphotropic transformation. Indeed, the shortest $\mathrm{Ag}-\mathrm{Ag}$ bonds in $\mathrm{Ag}_{3} \mathrm{AuSSe}$ and $\mathrm{Ag}_{3} \mathrm{AuS}_{1.5} \mathrm{Se}_{0.5}$ are equal to 2.99 and $3.01 \AA$, respectively, whereas the calculated value for the model petzite-like structure of $\mathrm{Ag}_{3} \mathrm{AuS}_{2}$ is $2.93 \AA$ (Seryotkin et al., 2013a).

The morphotropic transition of the same nature may be found in another chalcogenide series between acanthite $\mathrm{Ag}_{2} \mathrm{~S}$ (Frueh, 1958) and naummanite $\mathrm{Ag}_{2} \mathrm{Se}$ (Pingitore et al., 1992; Seryotkin et al., 2015). The compounds have distorted anion bcc arrangement with $\mathrm{Ag}^{+}$in planar ternary and distorted tetrahedral coordinations. Interestingly, the distortion of bcc arrangement is lower in monoclinic acanthite than in orthorhombic naumannite. There are short $\mathrm{Ag}-\mathrm{Ag}$ distances ranging in the interval 2.9-3.0 $\AA$ in the structure of naumannite. Partial substitution of selenium by sulfur results in a further shortening of the distances (Seryotkin et al., 2015). In the structure of acanthite $\mathrm{Ag}_{2} \mathrm{~S}$ the distribution of cations is slightly different and all $\mathrm{Ag}-\mathrm{Ag}$ distances are $\geq 3.0 \AA$. This can be considered as a cause of morphotropic transition in this series.

\section{Acknowledgements}

X-ray intensity data were collected at CRIST, Centro di Cristallografia Strutturale, University of Florence, Italy. This work was funded by "Progetto d'Ateneo 2013" issued to LB. The paper benefited by the official reviews made by Tonči Balić-Žunić, Peter Leverett and Ernst Spiridonov.

\section{REFERENCES}


Axtell, E.A., Liao, J.H. and Kanatzidis, M.G. (1998) Flux synthesis of LiAuS and NaAuS: "Chicken-wire-like" layer formation by interweaving of $(\mathrm{AuS})_{\mathrm{n}}{ }^{\mathrm{n}-}$ threads. Comparison with $\alpha-\mathrm{HgS}$ and AAuS (A = K, Rb). Inorganic Chemistry, 37, 5583-5587.

Bakakin, V.V. (2011) Crystal structures of gold, silver, and sodium chalcogenides: Sphenoidal interpretation. Crystallography Reports, 6, 970-979.

Bakakin, V.V. and Seryotkin, Yu.V. (2009) Unified formula and volume characteristics in comparative crystal chemistry of natural zeolites. Journal of Structural Chemistry, 50, S116-S123.

Barton, M.D., Kieft, C., Burke, E.A.J. and Oen, I.S. (1978) Uytenbogaardtite, a new silvergold sulfide. Canadian Mineralogist, 16, 651-657.

Bindi, L. (2008) Commensurate-incommensurate phase transition in muthmannite, AuAgTe 2 : First evidence of a modulated structure at low-temperature. Philosophical Magazine Letters, 88, 533-541.

Bindi, L. (2009) Thermal expansion behavior of empressite, AgTe: A structural study by means of in situ high-temperature single-crystal X-ray diffraction. Journal of Alloys and Compounds, 473, 262-264.

Bindi, L. and Cipriani, C. (2004a) Ordered distribution of Au and Ag in the crystal structure of muthmannite, $\mathrm{AuAgTe}$, a rare telluride from Sacarîmb, western Romania. American Mineralogist, 89, 1505-1509.

Bindi, L. and Cipriani, C. (2004b) Structural and physical properties of fischesserite, a rare gold-silver selenide from the De Lamar Mine, Owyhee County, Idaho, USA. Canadian Mineralogist, 42, 1733-1737.

Bindi, L. and Pingitore, N.E. (2013) On the symmetry and crystal structure of aguilarite, $\mathrm{Ag}_{4} \mathrm{SeS}$. Mineralogical Magazine, 77, 21-31. 
Bindi, L., Arakcheeva, A. and Chapuis, G. (2009) The role of silver on the stabilization of the incommensurately modulated structure in calaverite, $\mathrm{AuTe}_{2}$. American Mineralogist, 94, 728-736.

Bindi, L., Spry, P.G. and Cipriani, C. (2004) Empressite, AgTe, from the Empress-Josephine Mine, Colorado, USA: composition, physical properties and determination of the crystal structure. American Mineralogist, 89, 1043-1047.

Bindi, L., Stanley, C.J. and Spry, P.G. (2015) Cervelleite, $\mathrm{Ag}_{4} \mathrm{TeS}$ : solution and description of the crystal structure. Mineralogy and Petrology, 109, 413-419.

Cava, R.J., Reidinger, F. and Wuensch, B.J. (1980) Single-crystal neutron diffraction study of the fast-ion conductor $\beta-\mathrm{Ag}_{2} \mathrm{~S}$ between 186 and $325^{\circ} \mathrm{C}$. Journal of Solid State Chemistry, 31, 69-80.

Frueh, A.J.Jr. (1958) The crystallography of silver sulfide, $\mathrm{Ag}_{2} \mathrm{~S}$. Zeitschrift für Kristallographie, 110, 136-144.

Graf, R.B. (1968) The system $\mathrm{Ag}_{3} \mathrm{AuS}_{2}-\mathrm{Ag}_{2} \mathrm{~S}$. American Mineralogist, 53, 496-500.

Ibers, J.A. and Hamilton, W.C. Eds. (1974) International Tables for X-ray Crystallography, vol. IV, 366p. Kynock, Dordrecht, The Netherlands.

Ishikawa, K., Isonaga, T., Wakita, S. and Suzuki, Y. (1995) Structure and electrical properties of $\mathrm{Au}_{2} \mathrm{~S}$. Solid State Ionics, 79, 60-66.

Lima-de-Faria, J., Hellner, E., Liebau, F., Makovicky, E. and Parthe, E. (1990) Nomenclature of inorganic structure types. Acta Crystallographica, A46, 1-11.

Makovicky, E. (2006) Crystal structure of sulfides and other chalcogenides. Reviews in Mineralogy and Geochemistry, 61, 7-125.

Messien, P., Baiwir, M. and Tavernier, B. (1966) Structure cristalline du sulfure mixte d'argent et d'or. Bullettin de la Société Royale des Sciences de Liège, 56, 727-733. 
Oxford Diffraction (2006). CrysAlis RED (Version 1.171.31.2) and ABSPACK in CrysAlis RED. Oxford Diffraction Ltd, Abingdon, Oxfordshire, England.

Pingitore, N.E., Ponce, B.F., Eastman, M.P., Moreno, F. and Podpora, C. (1992) Solid solutions in the system $\mathrm{Ag}_{2} \mathrm{~S}-\mathrm{Ag}_{2} \mathrm{Se}$. Journal of Materials Research, 7, 2219-2224.

Seryotkin, Yu.V., Bakakin, V.V., Pal'yanova, G.A. and Kokh, K.A. (2011) Synthesis and crystal structure of the trigonal silver(I) dithioaurate(I), $\mathrm{Ag}_{3} \mathrm{AuS}_{2}$. Crystal Growth \& Design, 11, 1062-1066.

Seryotkin, Yu.V., Pal'yanova, G.A., Bakakin, V.V. and Kokh, K.A. (2013a) Synthesis and crystal structure of gold-silver sulfoselenides: morphotropy in the $\mathrm{Ag}_{3} \mathrm{Au}(\mathrm{Se}, \mathrm{S})_{2}$ series. Physics and Chemistry of Minerals, 40, 229-237.

Seryotkin, Yu.V., Pal'yanova, G.A. and Savva, N.E. (2013b) Sulfur-selenium isomorphous substitution and morphotropic transition in the $\mathrm{Ag}_{3} \mathrm{Au}(\mathrm{Se}, \mathrm{S})_{2}$ series. Russian Geology and Geophysics, 54, 646-651.

Seryotkin, Yu.V., Pal'yanova, G.A., Bakakin, V.V. and Kokh, K.A. (2014) Synthesis and crystal structure of silver-gold sulfide AgAuS. Four-fold interpenetrated threedimensional [( $\left.\mathrm{Au}, \mathrm{Ag})_{10} \mathrm{~S}_{8}\right]$-networks. CrystEngComm, 16, 1675-1680.

Seryotkin, Yu.V, Palyanova, G.A. and Kokh K.A. (2015) Sulfur-selenium isomorphous substitution and polymorphism in the $\mathrm{Ag}_{2}(\mathrm{Se}, \mathrm{S})$ series. Journal of Alloys and Compounds, 639, 89-93.

Sheldrick, G.M. (2008) A short history of SHELX. Acta Crystallographica, A64, 112-122.

Spreadborough, J. and Christian, J.W. (1959) High-temperature X-ray diffractometer. Journal of Scientific Instruments, 36, 116-118.

Yu, J. and Yun, H. (2011) Reinvestigation of the low-temperature form of $\mathrm{Ag}_{2} \mathrm{Se}$ (naumannite) based on single-crystal data. Acta Crystallographica, E67, i45. 
Fig. 3. Reflected light digital image with partially crossed polars illustrating the anisotropic rotation tints in the grain on the left as pale green (a) to deep purple (b). The grain on the right approaches isotropy and is close to being a basal section, i.e. $R_{0}$. 
Fig. 4. The structure of uytenbogaardtite. Projection along $c$-axis (a). The $\mathrm{Ag}_{12} \mathrm{Au}_{4} \mathrm{~S}_{20}$ building units seen from the top and their joining into column along three-fold symmetry axis seen from the side (b).

356

357 
TABLE 1. Data and experimental details for the selected uytenbogaardtite crystal

\section{Crystal data}

Formula

Crystal size (mm)

Form

Colour

Crystal system

Space group

a (A)

$c(\AA)$

$V\left(\AA^{3}\right)$

$Z$

\section{Data collection}

Instrument

Radiation type

Temperature $(\mathrm{K})$

Detector to sample distance $(\mathrm{cm})$

Number of frames

Measuring time (s)

Maximum covered $2 \theta\left(^{\circ}\right)$

Absorption correction

Collected reflections

Unique reflections

Reflections with $F_{\mathrm{o}}>4 \sigma\left(F_{\mathrm{o}}\right)$

$R_{\text {int }}$

Range of $h, k, l$
$\mathrm{Ag}_{3} \mathrm{AuS}_{2}$

$0.055 \times 0.061 \times 0.072$

block

black

Trigonal (hexagonal setting)

$R \overline{3} c$

$13.6952(5)$

$17.0912(8)$

2776.1(2)

24

Oxford Diffraction Xcalibur 3

$\operatorname{MoK} \alpha(\lambda=0.71073 \AA)$

293(2)

6

714

80

69.96

multi-scan (ABSPACK; Oxford Diffraction 2006)

47568

1099

907

0.032

$-15 \leq h \leq 16,-18 \leq k \leq 18,-27 \leq l \leq 27$

Full-matrix least squares on $F^{2}$

0.0137

0.0140

0.0321

38

0.93

1.81

$-1.78$ 
TABLE 2. Atoms, Wyckoff positions, atom coordinates and atomic displacement parameters $\left(\AA^{2}\right)$ for the selected uytenbogaardtite crystal

\begin{tabular}{|c|c|c|c|c|c|c|c|c|c|c|c|}
\hline atom & Wyckoff & $x$ & $y$ & $z$ & $U_{11}$ & $U_{22}$ & $U_{33}$ & $U_{12}$ & $U_{13}$ & $U_{23}$ & $U_{\text {iso }} * / U_{\text {eq }}$ \\
\hline Ag1 & $36 f$ & $0.04631(2)$ & $0.21652(2)$ & $0.33751(1)$ & $0.0157(1)$ & $0.0158(1)$ & $0.01536(9)$ & $0.00789(7)$ & $0.00004(6)$ & $0.00000(6)$ & $0.01558(5)$ \\
\hline Ag2 & $36 f$ & $0.83862(2)$ & $0.04245(2)$ & $0.42398(1)$ & $0.0166(1)$ & $0.0167(1)$ & $0.0164(1)$ & $0.00826(8)$ & $-0.00017(6)$ & $0.00002(6)$ & $0.01658(5)$ \\
\hline Aul & $6 a$ & 0 & 0 & 0.25 & $0.01502(8)$ & $0.01502(8)$ & $0.0146(1)$ & $0.00751(4)$ & 0 & 0 & $0.01486(6)$ \\
\hline $\mathrm{Au} 2$ & $18 e$ & $0.75437(1)$ & 0 & 0.25 & $0.01646(7)$ & $0.01648(8)$ & $0.01603(6)$ & $0.00824(4)$ & $0.00001(2)$ & $0.00002(4)$ & $0.01632(5)$ \\
\hline $\mathrm{S} 1$ & $12 c$ & 0 & 0 & $0.3887(1)$ & $0.0217(4)$ & $0.0217(4)$ & $0.0245(6)$ & $0.0108(2)$ & 0 & 0 & $0.0226(3)$ \\
\hline S2 & $36 f$ & $0.84379(8)$ & $0.18078(7)$ & $0.30325(5)$ & $0.0241(4)$ & $0.0244(4)$ & $0.0243(4)$ & $0.0122(3)$ & $-0.0002(3)$ & $0.0000(3)$ & $0.0243(2)$ \\
\hline
\end{tabular}


TABLE 3. Main interatomic distances $(\AA)$ for the selected uytenbogaardtite crystal

\begin{tabular}{|c|c|c|c|}
\hline $\mathrm{Ag} 1-\mathrm{S} 2^{i}$ & $2.6301(9)$ & $\mathrm{Au1}-\mathrm{S} 1^{x i i}$ & $2.370(2)$ \\
\hline $\mathrm{Ag} 1-\mathrm{S} 2^{i i}$ & $2.8207(9)$ & Au1-S1 & $2.370(2)$ \\
\hline Ag1-S1 & $2.8423(6)$ & Au1-Ag1 $1^{x i i i}$ & $3.0905(2)$ \\
\hline $\mathrm{Ag} 1-\mathrm{S} 2^{i i i}$ & $2.8795(9)$ & $\mathrm{Au} 1-\mathrm{Ag} 1^{x i i}$ & $3.0905(2)$ \\
\hline $\mathrm{Ag} 1-\mathrm{Au} 2^{i v}$ & $2.8998(3)$ & $\mathrm{Au} 1-\mathrm{Ag} 1^{x i v}$ & $3.0905(2)$ \\
\hline $\mathrm{Ag} 1-\mathrm{Au} 2^{v}$ & $2.9595(2)$ & $\mathrm{Au} 1-\mathrm{Ag} 1^{x v}$ & $3.0905(2)$ \\
\hline $\operatorname{Ag} 1-\operatorname{Ag} 2^{v}$ & $3.0062(3)$ & $\mathrm{Au} 1-\mathrm{Ag} 1^{v i}$ & $3.0905(2)$ \\
\hline $\operatorname{Ag} 1-\operatorname{Ag} 2^{i}$ & $3.0294(3)$ & $\mathrm{Au} 1-\mathrm{Au} 2^{v}$ & $3.3640(2)$ \\
\hline Ag1-Au1 & $3.0905(2)$ & $\mathrm{Au} 1-\mathrm{Au} 2^{i}$ & $3.3640(2)$ \\
\hline $\mathrm{Ag} 1-\mathrm{Ag} 1^{v i}$ & $3.1865(5)$ & $\mathrm{Au} 1-\mathrm{Au} 2^{x v i}$ & $3.3640(2)$ \\
\hline $\mathrm{Ag} 1-\mathrm{Ag} 1^{v i i}$ & $3.2523(4)$ & $\mathrm{Au} 2-\mathrm{S} 2^{x i i i}$ & $2.3294(9)$ \\
\hline $\mathrm{Ag} 2-\mathrm{S} 2^{v i i i}$ & $2.546(1)$ & $\mathrm{Au} 2-\mathrm{S} 2$ & $2.3294(9)$ \\
\hline $\mathrm{Ag} 2-\mathrm{S} 1^{i x}$ & $2.6215(5)$ & $\mathrm{Au} 2-\mathrm{Ag} 1^{x v i i}$ & $2.8998(3)$ \\
\hline $\mathrm{Ag} 2-\mathrm{S} 2^{x}$ & $2.6278(9)$ & Au2-Ag $1^{x v i i i}$ & $2.8999(3)$ \\
\hline Ag2-S2 & $2.7780(9)$ & $\mathrm{Au} 2-\mathrm{Ag} 1^{x i x}$ & $2.9595(2)$ \\
\hline $\operatorname{Ag} 2-\operatorname{Ag} 1^{x i}$ & $3.0062(3)$ & $\mathrm{Au} 2-\operatorname{Ag} 1^{x i}$ & $2.9595(2)$ \\
\hline $\operatorname{Ag} 2-\operatorname{Ag} 1^{i x}$ & $3.0294(3)$ & $\mathrm{Au} 2-\mathrm{Ag} 2^{x i i i}$ & $3.1369(3)$ \\
\hline $\operatorname{Ag} 2-\operatorname{Ag} 2^{\text {viii }}$ & $3.0821(4)$ & $\mathrm{Au} 2-\mathrm{Au} 1^{i x}$ & $3.3640(2)$ \\
\hline Ag2-Au2 & $3.1369(3)$ & & \\
\hline
\end{tabular}

Symmetry codes: (i) $x-1, y, z$; (ii) $x-2 / 3, x-y-1 / 3, z+1 / 6$; (iii) $-x+1,-x+y+1,-z+1 / 2 ;$ (iv) $x-y-2 / 3, x-1 / 3,-z+2 / 3 ;$ (v) $-x+y+1$, $-x+1, z$; (vi) $-x,-x+y,-z+1 / 2$; (vii) $-x+1 / 3,-y+2 / 3,-z+2 / 3$;

(viii) $y+2 / 3, x-2 / 3,-z+5 / 6$; (ix) $x+1, y, z ;(x)-x+y+4 / 3, y-1 / 3$, $z+1 / 6$; (xi) $-y+1, x-y, z$; (xii) $y, x,-z+1 / 2$; (xiii) $x-y,-y,-z+1 / 2$; (xiv) $-x+y,-x, z ;(x v)-y, x-y, z ;(x v i)-y, x-y-1, z ;(x v i i) y+1 / 3$, $-x+y-1 / 3,-z+2 / 3 ;(x v i i i) x+2 / 3, x-y+1 / 3, z-1 / 6 ;$ (xix) $-x+1,-x+y$, $-z+1 / 2$. 
TABLE 4. Structural characteristics of silver and gold sulfides, sulfoselenides and selenides (Ag,Au) $2 \mathrm{n}(\mathrm{S}, \mathrm{Se})_{\mathrm{n}}$.

\begin{tabular}{|c|c|c|c|c|c|c|c|c|c|c|c|}
\hline \multirow[b]{2}{*}{ Series } & \multirow[b]{2}{*}{ Compound (mineral) } & \multirow[b]{2}{*}{ Type } & \multicolumn{4}{|c|}{ Unit-cell parameters ( $\AA$, degrees) } & \multirow{2}{*}{\multicolumn{2}{|c|}{ Space group, Z }} & \multirow{2}{*}{$\begin{array}{l}V_{\mathrm{N}} \\
\left(\AA^{3}\right)\end{array}$} & \multirow[b]{2}{*}{ Crystal-chemical formula } & \multirow[b]{2}{*}{ Reference } \\
\hline & & & $a$ & $b$ & $c$ & $\beta$ & & & & & \\
\hline \multirow{8}{*}{ 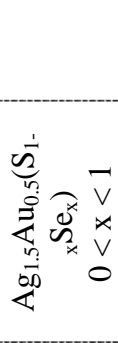 } & $\mathrm{Au}_{2} \mathrm{~S}$ & I & 5.0206 & - & - & & $P n \overline{3} m$ & 2 & 21.1 & \multirow{2}{*}{$\begin{array}{l}{ }^{[2]} \mathrm{Au}_{2}{ }^{(4)} \mathrm{S} \\
{ }^{[4]} \mathrm{Ag}_{3}\left[{ }^{[2]} \mathrm{Ag}^{[2]} \mathrm{Au}_{4}{ }^{(4)} \mathrm{S}^{(6)} \mathrm{S}_{3}\right]\end{array}$} & Ishikawa et al. (1995) \\
\hline & AgAuS (petrovskaite) & II & 13.4235 & - & 9.0873 & & $R \overline{3} m$ & 24 & 19.7 & & Seryotkin et al. (2014) \\
\hline & $\mathrm{Ag}_{3} \mathrm{AuS}_{2}$ (uytenbogaardtite) & III & 13.6952 & - & 17.0912 & & $R \overline{3} c$ & 24 & 19.3 & \multirow{6}{*}{$\begin{array}{l}{ }^{[4]} \mathrm{Ag}_{3}{ }^{[2]} \mathrm{Au}^{(7)} \mathrm{S}_{2} \\
{ }^{[4]} \mathrm{Ag}_{3}{ }^{[2]} \mathrm{Au}^{(7)}(\mathrm{S}, \mathrm{Se})_{2} \\
{ }^{[4]} \mathrm{Ag}_{3}{ }^{[2]} \mathrm{Au}^{(7)}(\mathrm{S}, \mathrm{Se})_{2} \\
{ }^{[4]} \mathrm{Ag}_{3}{ }^{[2]} \mathrm{Au}^{(7)}(\mathrm{S}, \mathrm{Se})_{2} \\
{ }^{[4]} \mathrm{Ag}_{3}{ }^{[2]} \mathrm{Au}^{(7)} \mathrm{Se}_{2}\end{array}$} & This work \\
\hline & & & 13.7104 & & 17.1170 & & & & 19.4 & & Seryotkin et al. (2011) \\
\hline & $\mathrm{Ag}_{3} \mathrm{Au}\left(\mathrm{S}_{1.5} \mathrm{Se}_{0.5}\right)$ & III & 13.7752 & - & 17.2098 & & $R \overline{3} c$ & 24 & 19.6 & & Seryotkin et al. (2013a) \\
\hline & $\mathrm{Ag}_{3} \mathrm{Au}\left(\mathrm{S}_{1.0} \mathrm{Se}_{1.0}\right)$ & IV & 9.8633 & - & - & & $I 4_{1} 32$ & 8 & 20.0 & & Seryotkin et al. (2013a) \\
\hline & $\mathrm{Ag}_{3} \mathrm{Au}\left(\mathrm{S}_{0.5} \mathrm{Se}_{1.5}\right)$ & IV & 9.9241 & - & - & & $I 4_{1} 32$ & 8 & 20.4 & & Seryotkin et al. (2013a) \\
\hline & $\mathrm{Ag}_{3} \mathrm{AuSe}_{2}$ (fischesserite) & IV & 9.965 & - & - & & $I 4,32$ & 8 & 20.6 & & Bindi and Cipriani (2004b) \\
\hline \multirow{5}{*}{ 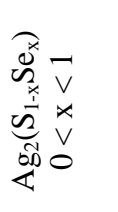 } & $\mathrm{Ag}_{2} \mathrm{~S}$ (acanthite) & $\mathbf{V}$ & 4.23 & 6.91 & 7.87 & 99.58 & $P 2_{1} / n$, & 4 & 18.9 & ${ }^{[3+1]} \mathrm{Ag}^{[2+1]} \mathrm{Ag}^{(5+2)} \mathrm{S}$ & Frueh (1958) \\
\hline & $\mathrm{Ag}_{2}\left(\mathrm{~S}_{0.5} \mathrm{Se}_{0.5}\right)$ (aguilarite) & V & 4.2478 & 6.9432 & 8.0042 & 100.103 & $P 2_{1} / n$ & 4 & 19.4 & ${ }^{[+1]} \mathrm{Ag}^{[2+1]} \mathrm{Ag}^{(5+2)}(\mathrm{S}, \mathrm{Se})$ & Bindi and Pingitore (2013) \\
\hline & $\mathrm{Ag}_{2}\left(\mathrm{~S}_{0.25} \mathrm{Se}_{0.75}\right)$ & $\mathbf{V}$ & 4.2716 & 6.9707 & 8.1113 & 100.802 & $P 2_{1} / n$ & 4 & 19.8 & ${ }^{[3+1]} \mathrm{Ag}^{[2+1]} \mathrm{Ag}^{(5+2)}(\mathrm{S}, \mathrm{Se})$ & Seryotkin et al. (2015) \\
\hline & $\mathrm{Ag}_{2}\left(\mathrm{~S}_{0.33} \mathrm{Se}_{0.67}\right)$ & VI & 4.2845 & 7.001 & 7.739 & & $P 2_{1} 2_{1} 2_{1}$ & 4 & 19.35 & ${ }^{[4]} \mathrm{Ag}^{[3]} \mathrm{Ag}^{(7)}(\mathrm{S}, \mathrm{Se})$ & Seryotkin et al. (2015) \\
\hline & $\mathrm{Ag}_{2} \mathrm{Se}$ (naumannite) & VI & 4.3359 & 7.070 & 7.774 & & $P 2_{1} 2_{1} 2_{1}$ & 4 & 19.9 & ${ }^{[4]} \mathrm{Ag}^{[3]} \mathrm{Ag}^{(7)} \mathrm{Se}$ & Yu and Yun (2011) \\
\hline
\end{tabular}

Note. Isostructural compounds are shown by same Roman letters. 


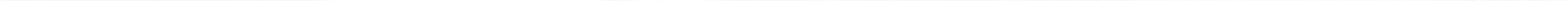




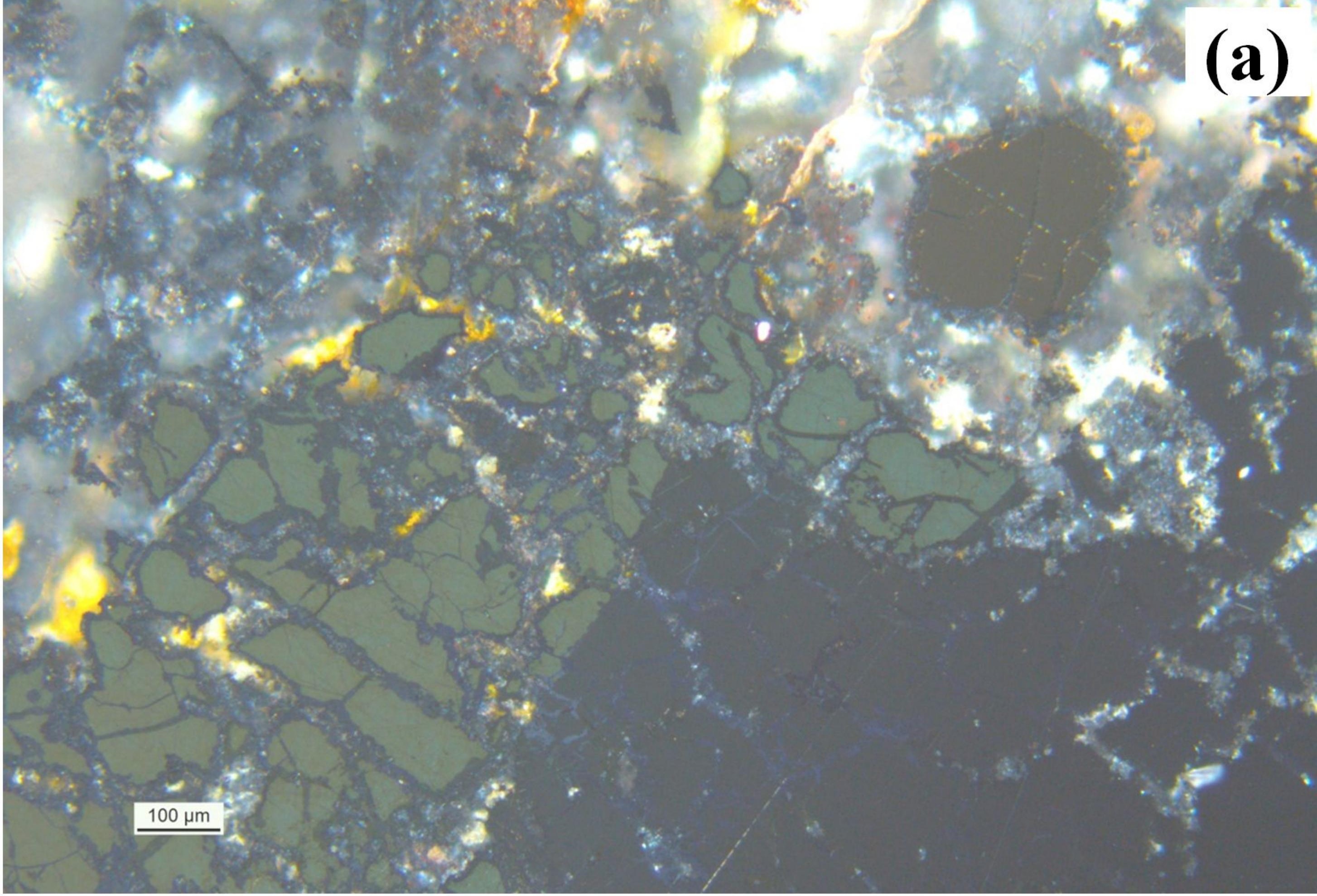

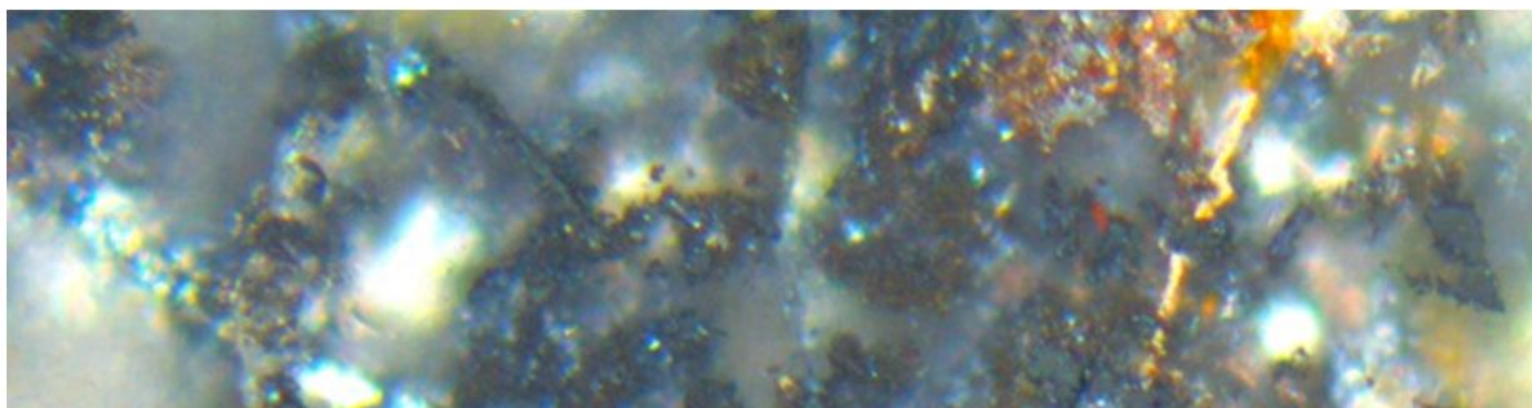

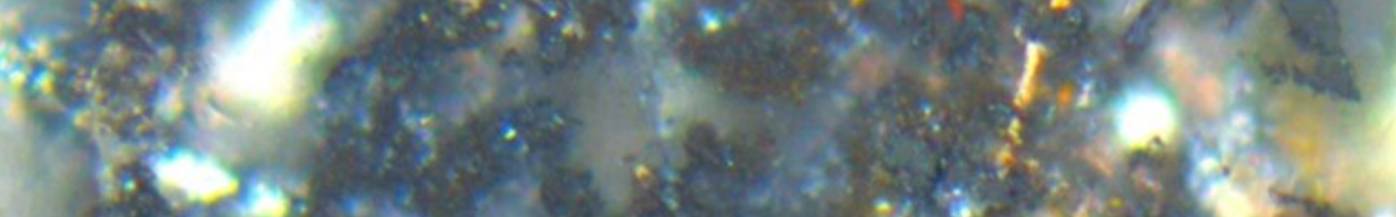

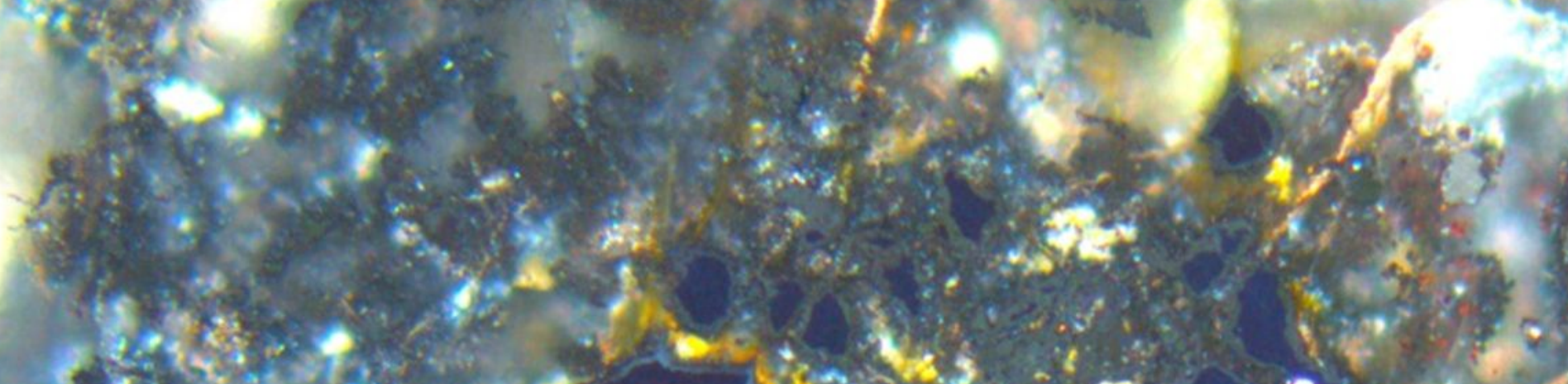

$3 \times+40$ (b)

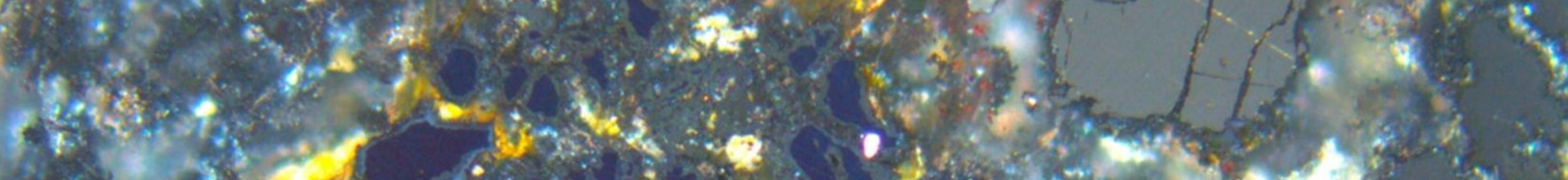

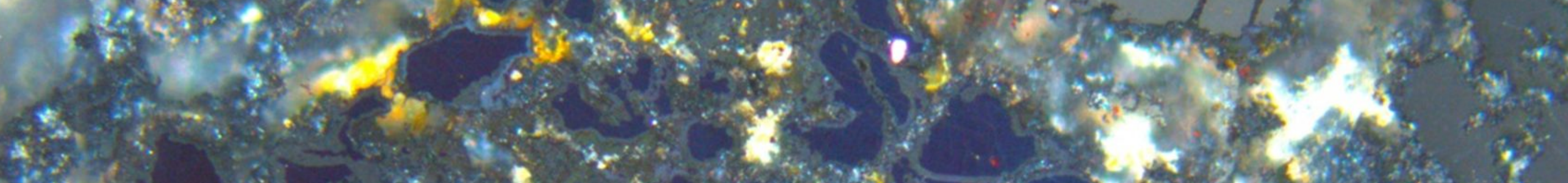

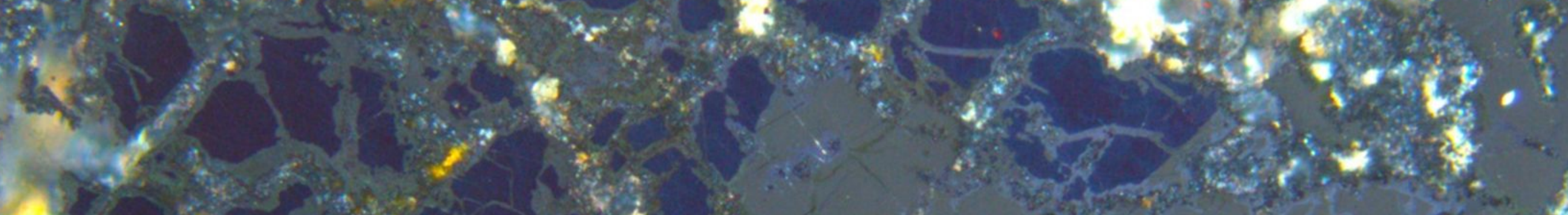

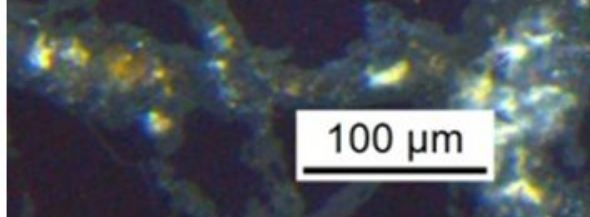



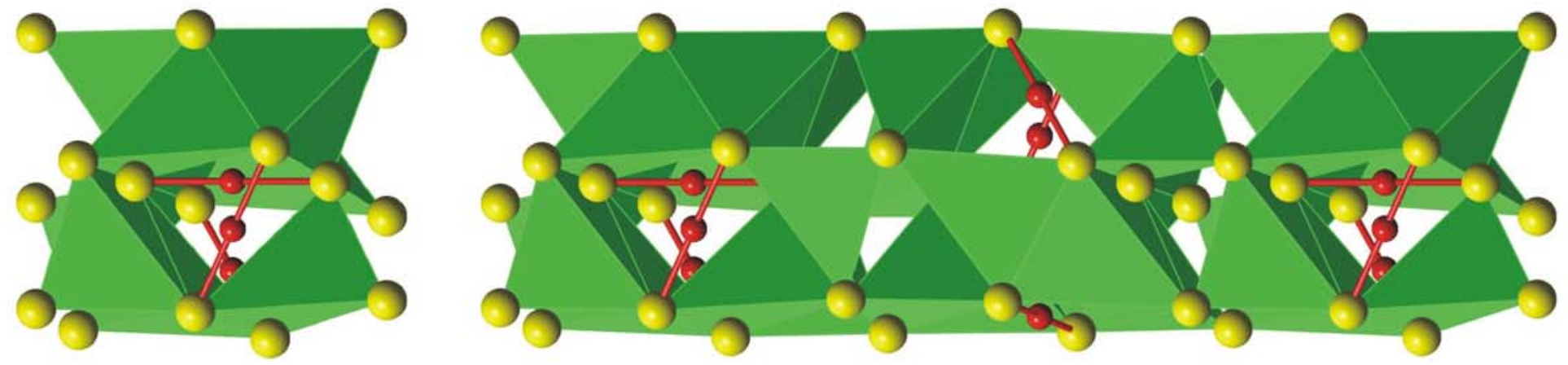

$\widehat{\mathrm{a}}$

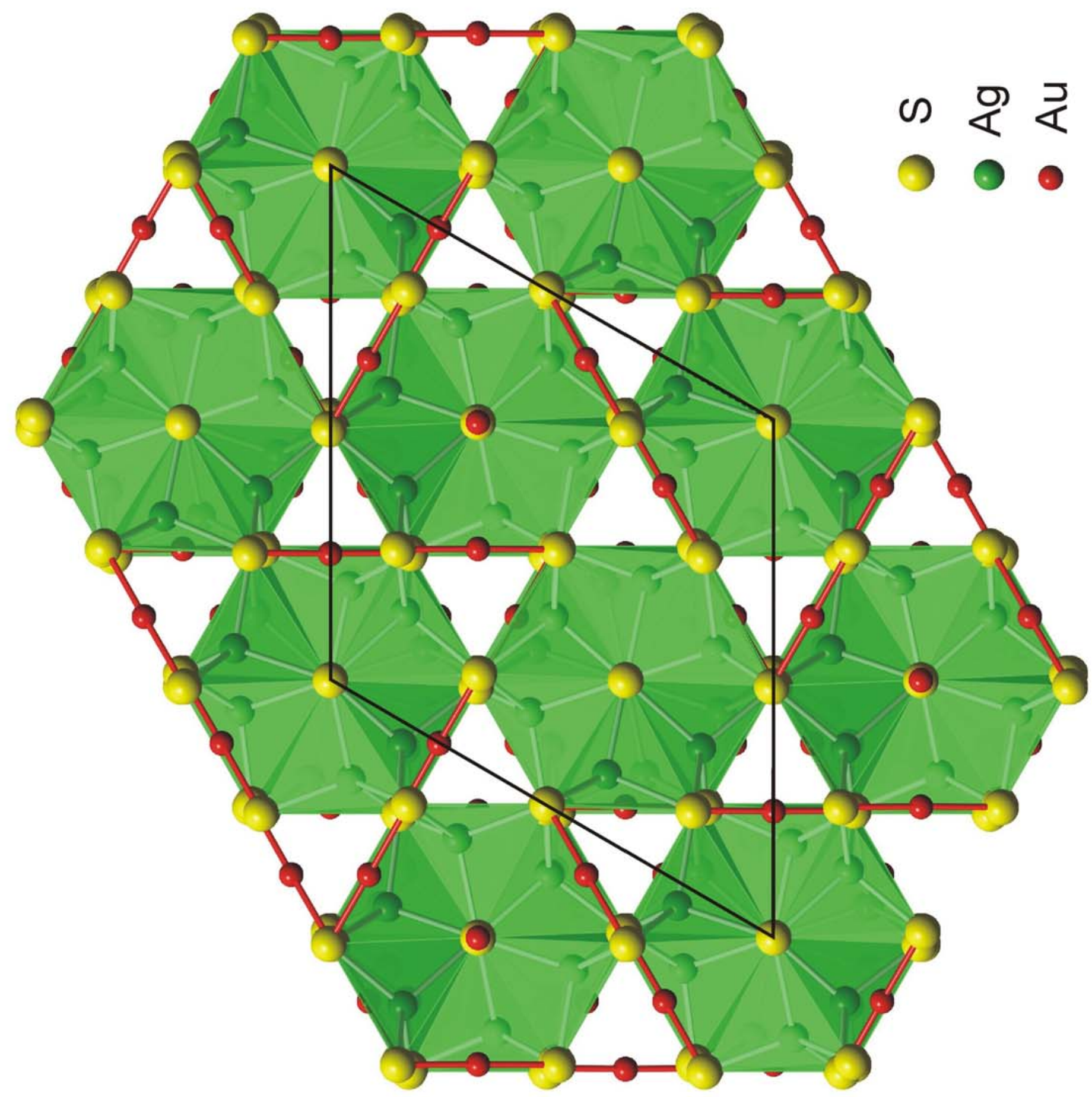

(0)

This is a 'preproof' accepted article for Mineralogical Magazine.

This version may be subject to change during the production process. DOI: 10.1180/minmag.2016.080.041 